\title{
Modelling the response of an alluvial aquifer to anthropogenic and recharge stresses in the United States Southern Great Plains
}

\author{
Joseph T Zume ${ }^{1, *}$ and Aondover A TArhule ${ }^{2}$ \\ ${ }^{1}$ Department of Geography and Earth Science, Shippensburg University, \\ 1871 Old Main Drive, Shippensburg, PA 17257, USA. \\ ${ }^{2}$ Department of Geography, University of Oklahoma, 100 East Boyd Street, \\ SEC 684, Norman, OK 73019, USA. \\ *e-mail: jtzume@ship.edu
}

This paper uses Visual MODFLOW to simulate potential impacts of anthropogenic pumping and recharge variability on an alluvial aquifer in semi-arid northwestern Oklahoma. Groundwater withdrawal from the aquifer is projected to increase by more than $50 \%$ (relative to 1990) by the year 2050 . In contrast, climate projections indicate declining regional precipitation over the next several decades, creating a potential problem of demand and supply. The following scenarios were simulated: (1) projected groundwater withdrawal, (2) a severe drought, (3) a prolonged wet period, and (4) a human adjustment scenario, which assumes future improvements in water conservation measures. Results indicate that the combined impacts of anthropogenic pumping and droughts would create drawdown of greater than $12 \mathrm{~m}$ in the aquifer. Spatially, however, areas of severe drawdown will be localized around large-capacity well clusters. The worst impacts of both pumping and droughts will be on stream-aquifer interaction. For example, the projected aquifer pumpage would lead to a total streamflow loss of $40 \%$, creating losing stream system regionally. Similarly, a severe drought would lead to a total streamflow loss of $>80 \%$. A post-audit of the model was also carried out to evaluate model performance. By simulating various stress scenarios on the alluvial aquifer, this study provides important information for evaluating management options for alluvial aquifers.

\section{Introduction}

Semi-arid northwestern Oklahoma, on the southern Great Plains of the United States, is facing a dilemma. On the one hand, climate reports (USGCRP 2000; Christensen et al 2007) indicate that the region will likely to experience a decrease in mean annual precipitation over the next few decades. On the other hand, regional demand for freshwater is rising. For example, using the 1990 regional water demand as the base, the Oklahoma Water Resources Board (OWRB) projects an increased demand of $>50 \%$ by the year 2050 (OWRB 1997). This situation would create a gap between supply and demand.

Although several modelling studies have investigated impacts of anthropogenic water demand and or climate variability/change on bedrock aquifers (e.g., Rosenberg et al 1999; Loáiciga et al 2000; Chen et al 2001; Eckhardt and Ulbrich 2003;

Keywords. Numerical modelling; northwestern Oklahoma; MODFLOW; alluvial aquifers; recharge variability; US Southern Great Plains; Hydrology; modelling; coupled systems; general/other. 
Brouyère et al 2004; Holman 2006), comparatively fewer have focused on shallow alluvial aquifers (e.g., Chen and Chen 2004; Don et al 2005; Alemayehu et al 2007; Rejani et al 2007). The work by Alemayehu et al (2007), for example, found that anthropogenic overexploitation of an alluvial aquifer in eastern Ethiopia, has dried up two important lakes by compromising baseflow contribution to the lakes. Similarly, Rejani et al (2007) reported negative impacts induced by overexploitation of a coastal alluvial aquifer in India. These studies, among others, have highlighted the need for understanding the response of alluvial aquifers both to anthropogenic and climatic stresses. This need is even more critical for semiarid environments, where alluvial aquifers are often the most important sources for freshwater. The present study focuses on a shallow alluvial aquifer in semi-arid northwestern Oklahoma. A pioneering study of the aquifer by Davis and Christenson (1981) simulated the impacts of aquifer pumping on groundwater levels and streamflow using a 2-dimensional (2-D) groundwater flow model. However, a 2-D model does not account for vertical flows that are generated around pumping wells and stream-aquifer contacts. Therefore, to more fully represent aquifer complexity this study utilized a 3-dimensional flow model. A derivative of the study that examined specifically, the impacts of aquifer pumping on stream-aquifer interaction, has already been published (see Zume and Tarhule 2008). This part of the study evaluates the response of the entire aquifer to the combined impacts of groundwater withdrawal and climate-driven recharge variability.

The importance of alluvial aquifers in arid and semi-arid world regions is evident (e.g., Workman and Serrano 1999; Bronstert et al 2000; Cui and Shao 2005). Besides supporting various human agro-economic activities, they are critical for maintaining streamflow during dry periods, and for sustaining riparian biodiversity. On the African Sahel savanna, for example, where water supplies are still largely dependent on unregulated natural sources, settlements often are clustered within alluvial basins because their shallow groundwater systems provide remarkable defense against the region's persistent droughts (Cater and Alkali 1996; Tarhule and Woo 1997, 2002). On the Southern Great Plains of the United States, a report by Ryder (1996) indicates that some alluvial aquifers have higher yields than adjacent bedrock aquifers. Consequently, alluvial aquifers are exploited extensively for irrigation, and have contributed to making the Southern Plains one of the most agriculturally productive regions of the United States. Yet, the region is prone to episodic droughts with attendant water shortages
(Covich et al 1997; Zume and Tarhule 2006). For northwestern Oklahoma, projected demand on shallow groundwater and recurring droughts threaten the region's agricultural and economic base. Simulating the response of the region's most important alluvial aquifer to anthropogenic demand and recharge variability will provide information that can be used for evaluating management options for the aquifer.

This study simulates the response of the Alluvium and Terrace aquifer (A\&T aquifer for brevity) along the Beaver-North Canadian River (BNCR) in northwestern Oklahoma to the impacts of anthropogenic water withdrawals and climate variability. Groundwater simulation attempts to replicate real-world complexity by integrating components of the physical hydrogeologic system, climatic and anthropogenic stresses, thereby providing multifaceted insights about system dynamics, including future outlooks (e.g., Abderrahman and Rasheeduddin 1994; Kirshen 2002; Senthilkumar and Elango 2004; Rainwater et al 2005).

\section{The study area}

\subsection{Location, physiography and climate}

The A\&T aquifer (figure 1) is a critical source of fresh water that supplies most of northwestern Oklahoma's water for domestic, irrigation, municipal, stock, and industrial purposes (Adams et al 1997). The aquifer spans an area of $2150 \mathrm{~km}^{2}$ and is located within the western sand-dune belt geomorphic province of northwestern Oklahoma. The land surface elevation decreases from approximately $700 \mathrm{~m}$ above mean sea level (m.a.s.l) in the northwestern part to approximately $490 \mathrm{~m}$ in the southeast (Davis and Christenson 1981). The climate of northwestern Oklahoma is semi-arid, having a mean annual precipitation of approximately $660 \mathrm{~mm}$. Eighty three percent of the precipitation falls between March and October but the months of May and June receive the largest amounts of the total precipitation (16\% and 13\%, respectively). Year-to-year precipitation variability is high with a coefficient of variability of $19 \%$. As a result, the region is drought-prone (see figure 2), characterized by sporadic water shortages with severe adverse implications for agricultural and other economic activities. Surface drainage network in the area is sparse and annual evaporative losses are high, ranging spatially between 1422 and $1626 \mathrm{~mm}$ (OWRB 1997). Annual evaporation far exceeds annual precipitation, on average, about $230 \%$ of regional annual precipitation (OWRB 1997). The high evaporative demand on surface water resources has also created problems 


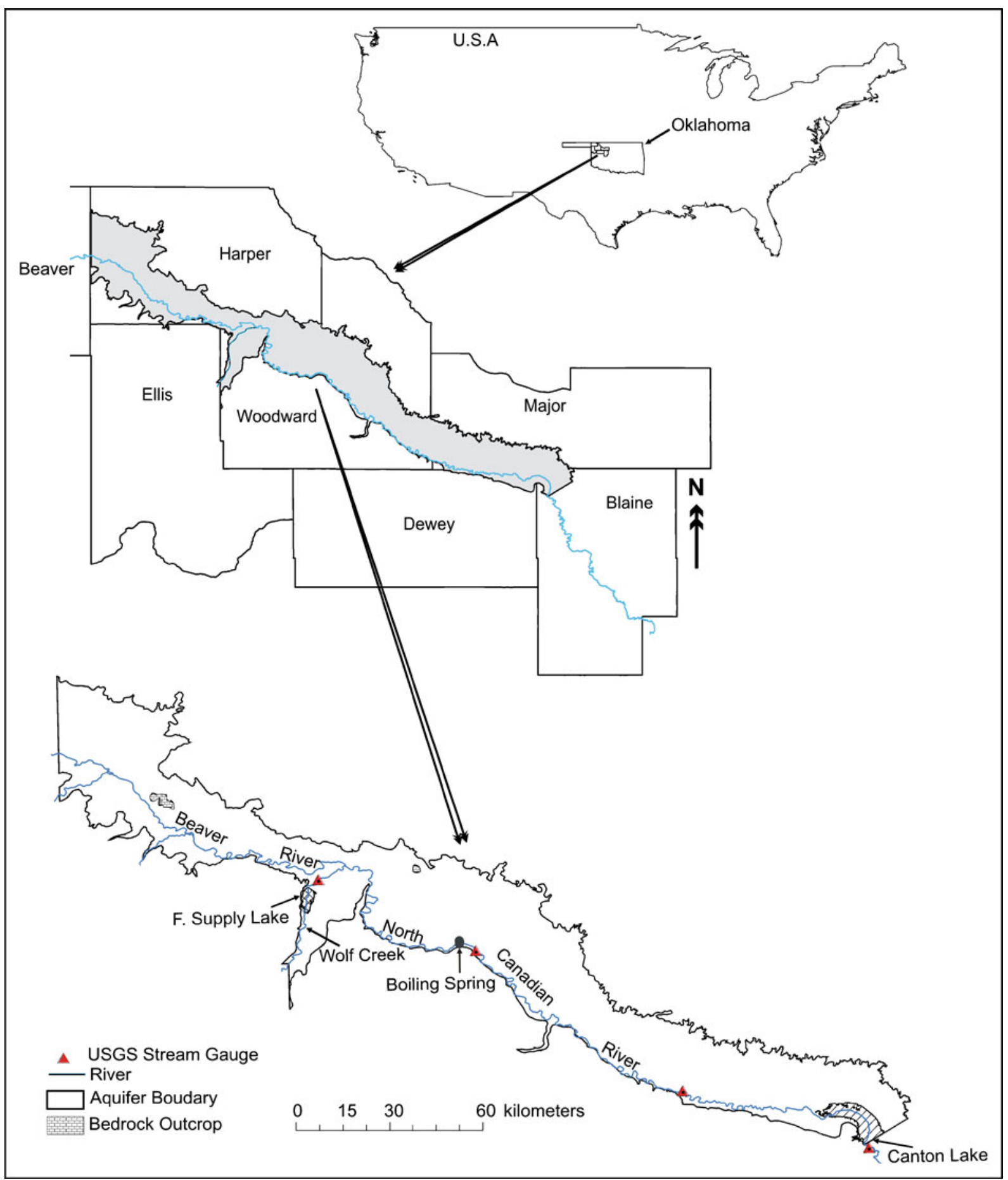

Figure 1. Study area map.

of surface water quality. The combined effects of sparse surface sources, unreliable streamflows, and poor surface water quality, have created a heavy dependence on the A\&T aquifer.

\subsection{Hydrogeology}

The A\&T aquifer is composed primarily of Quaternary deposits, which occur mainly north of the BNCR (Davis and Christenson 1981). These deposits are oriented concordantly relative to the river, the result of the river's southerly migration down the regional dip of the underlying Red Beds and the influence of dominant southerly winds. The Quaternary deposits consist of four geologic units: the high and low terrace deposits, the alluvium, and the dune sands. The thicknesses of these deposits vary spatially. The high terrace deposits, which occur farthest from the present river channel, vary in thickness from 0 to $91 \mathrm{~m}$, with an 


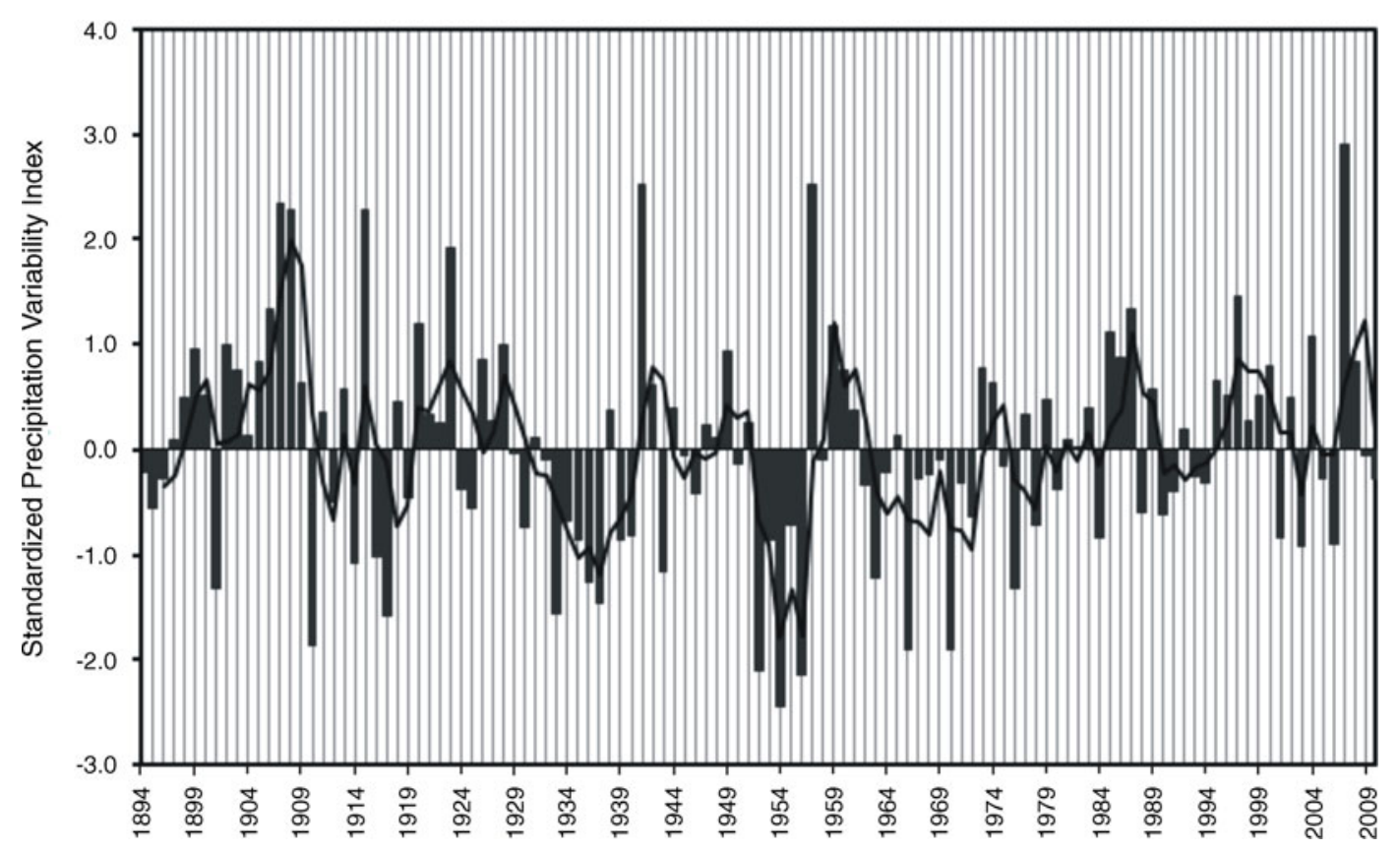

Figure 2. Standardized precipitation index (anomaly) plot for northwestern Oklahoma (1894-2010). Thick line is the 3-year running mean.

average of approximately $20 \mathrm{~m}$. These deposits are of Pleistocene age, and are believed to have been derived by the reworking of the Ogallala and the adjacent Permian Formations (Davis and Christenson 1981). The low terrace deposits average about $15 \mathrm{~m}$ in thickness. The main river channel and its floodplain are largely made up of alluvial deposits of Holocene age and have an average thickness of about $9 \mathrm{~m}$. Overlying most of the study area are dune sands, which are derived from the underlying terrace and alluvium deposits. The dune sands are unsaturated usually but greatly facilitate recharge to the alluvial aquifer. The terrace and alluvium deposits are the principal water-bearing units. They are comprised of poorly sorted, fine to coarsegrained, unconsolidated quartz sand, containing minor amounts of clay, silt, and basal gravel (Davis and Christenson 1981). It is believed that the alluvium and terrace deposits are hydraulically connected and constitute a single aquifer unit that is generally unconfined. Information from drillers' logs supplied by the OWRB suggests the top of the Permian Red Beds Formation forms the base of the aquifer at most locations. The Red Beds are relatively impermeable and act as a barrier to vertical water leakage from the aquifer. Depth to bedrock varies spatially with a maximum of about $100 \mathrm{~m}$. At a few locations however, the bedrock outcrops at the surface. The Tertiary Ogallala and the Rush Springs Formations underlie the aquifer in the northwestern corner.

The Beaver and the North Canadian rivers, together with their tributaries drain the study area. The Beaver River enters Oklahoma from New Mexico. It flows, first easterly, then southeasterly, becoming the headwaters of the North Canadian River at its confluence with Wolf Creek (figure 1). Known as the North Canadian from this point downstream (except at its length through Oklahoma City where it has recently been designated the Oklahoma City river), the river continues its southeasterly flow across central Oklahoma before joining the Canadian River to empty into the Arkansas. Davis and Christenson (1981), coined the term 'Beaver-North Canadian River' to refer to the combined river channels of the Beaver and the North Canadian rivers. Joining the BNCR from the south are a few seasonal tributary streams that drain the southern areas underlain by Permian and Tertiary Formations. Two storage reservoirs are located on the river in the study area. Fort Supply Lake is located on Wolf Creek in Woodward County. Further downstream on the North Canadian River, Lake Canton is located near the city of Canton in Blain County (figure 1).

\subsection{Data used for the study}

Data and other relevant information used for this study were obtained from different sources. Principal sources of data include the OWRB, the United States Geological Survey (USGS), the Oklahoma Climatological Survey (OCS), the United States Army Corps of Engineers (USACE), and the United States Environmental Protection Agency 
(USEPA). The USEPA's BASINS programme provided the digital data for all stream segments in the study area. A summary of the data and their sources are provided in table 1 . Specifics about how each dataset were used are discussed in the relevant sections below.

\section{Numerical simulation}

\subsection{Model conceptualization and development}

A three dimensional groundwater flow model with variable spatial resolution was implemented using the USGS groundwater flow code, MODFLOW (McDonald and Harbaugh 1988). Visual MODFLOW, a proprietary product of Waterloo Hydrogeologic Inc. (2005), was used as a pre- and postprocessor for the USGS MODFLOW. As evidenced by its wide usage, MODFLOW has become the industry standard for groundwater flow and transport modelling (e.g., Varni and Usunoff 1999; Wilsnack et al 2001; Kirshen 2002; Croley and Luukkonen 2003). The interested reader can refer to the site, igwmc.mines.edu/events/, for more information on MODFLOW.

In this study, the A\&T aquifer was discretized into a finite-difference grid, comprising 187 rows and 232 columns oriented in the direction of regional groundwater flow. Cell sizes were set at $0.35 \mathrm{~km}$ per side but finer grid refinement was used around pumping wells, stream segments, and other model boundaries, where large variations in hydraulic gradients are expected over small spatial scales (see Mehl et al 2006). Vertically, the aquifer was divided into three model layers of variable thicknesses based on lithologic information from well $\operatorname{logs}$ as well as well-completion reports provided by the OWRB for the aquifer. The top layer varied in thickness from 0 to $26 \mathrm{~m}$, while the second and the third layers reached maximum thicknesses of 43 and $31 \mathrm{~m}$, respectively. Surface elevations were derived from a USGS digital elevation model (DEM; 7.5-minute, $30 \times 30 \mathrm{~m}$ resolution).
To incorporate the spatial distribution of hydraulic conductivity $(K)$ over the aquifer, active cells in model layer 1 were initially grouped into eight $K$ zones based on surface geology and average yields of well clusters within the aquifer. The zones were replicated in layers 2 and 3 . Both the zones, and the initial $\mathrm{K}$ values, were refined during model calibration. For all zones, a horizontal to vertical hydraulic conductivity $\left(K_{h} / K_{v}\right)$ ratio of 10 was assumed. A uniform initial specific yield value of 0.25 was assigned to all model layers and adjusted during model calibration. To avoid problems of numerical instability all model layers were simulated as confined during the steady-state run.

\subsection{Boundary conditions}

Figure 3 shows the grid layout and the boundary conditions used in simulating flow in the A\&T aquifer. The active area of the model was bounded by no-flow cells. Also, the aquifer base was treated as a no-flow boundary, consistent with the regional bedrock geology. At the upstream end of the Beaver River, where a narrow strip of alluvial deposits extends beyond the geographic limit of the study area, a general head boundary was applied to simulate subsurface inflow to the model domain on both sides of the river. Similarly, a general head boundary was used to simulate subsurface outflow from the alluvium at the downstream end of the North Canadian River.

The aquifer water table elevation map (for predevelopment conditions) suggests that subsurface inflow from the Ogallala Formation into the aquifer occurs around the northwestern side of the study area (e.g., Davis and Christenson 1981). This influx was simulated by placing constant flux nodes in model layers two and three. Similarly, there is indication of subsurface leakage from the aquifer into adjacent groundwater basins at several locations. These leakages were simulated with drain cells in the first and second model layers (see figure 3).

Table 1. Summary of data used for the study.

\begin{tabular}{|c|c|c|c|}
\hline Data & Source & Duration & Time scale \\
\hline Precipitation & OCS & $1894-2003$ & Monthly \\
\hline Streamflow & USGS & $1905-2004$ & Monthly \\
\hline Stream segments data & BASINS, USEPA & $\mathrm{N} / \mathrm{A}$ & $\mathrm{N} / \mathrm{A}$ \\
\hline GW level & OWRB & 1976-2004 & Annually \\
\hline Spring discharge & Boiling Springs Park office & 1998-2004 & Monthly \\
\hline GW pumping & OWRB & $1975-2004$ & Annually \\
\hline Land surface elev. & USGS 7.5 min DEM $(30 \times 30 \mathrm{~m}$ resolution $)$ & $\mathrm{N} / \mathrm{A}$ & $\mathrm{N} / \mathrm{A}$ \\
\hline Aquifer parameters & USGS and OWRB & $\mathrm{N} / \mathrm{A}$ & $\mathrm{N} / \mathrm{A}$ \\
\hline Lake stages & USACE & $1984-2003$ & Monthly \\
\hline
\end{tabular}




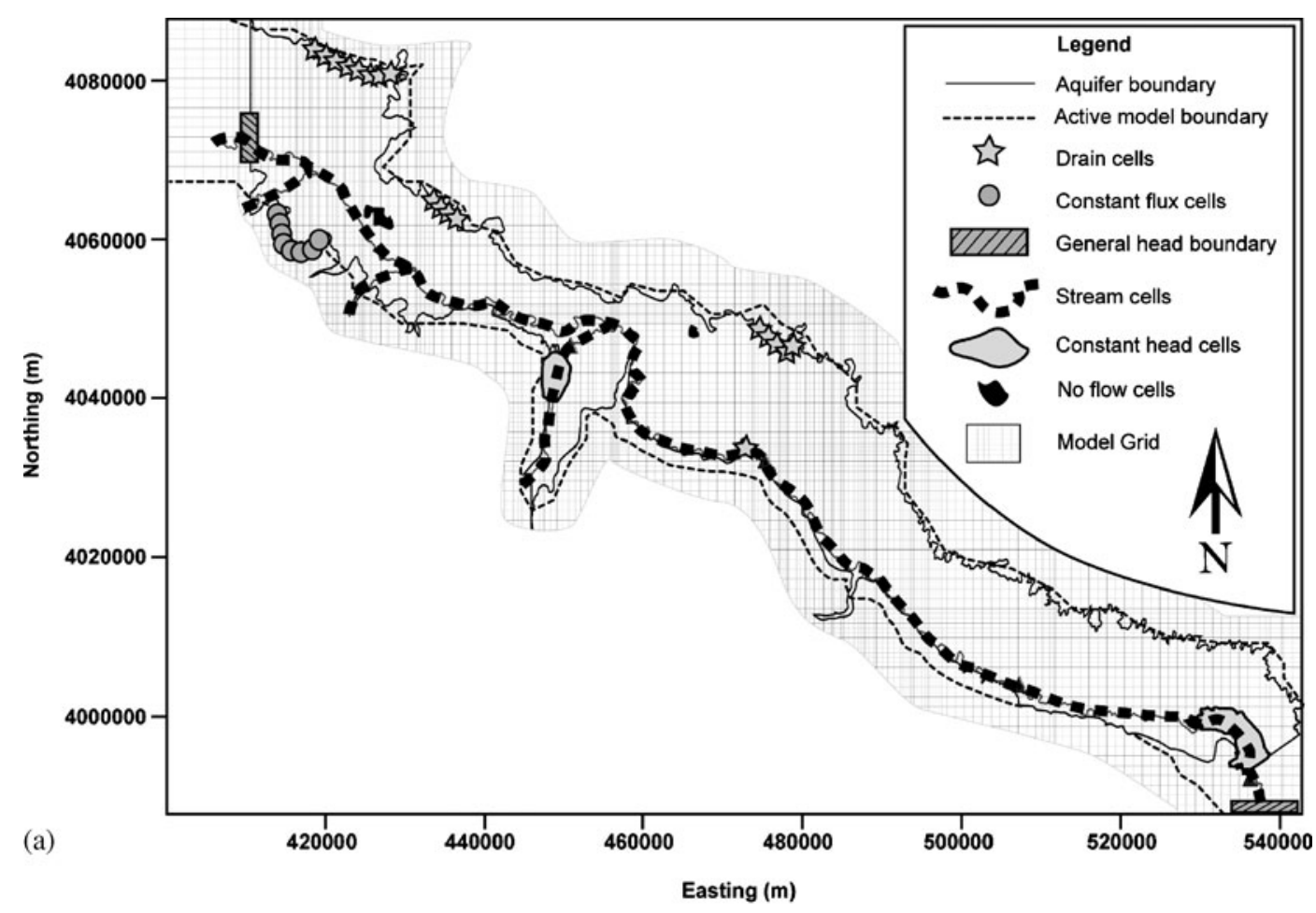

(b)

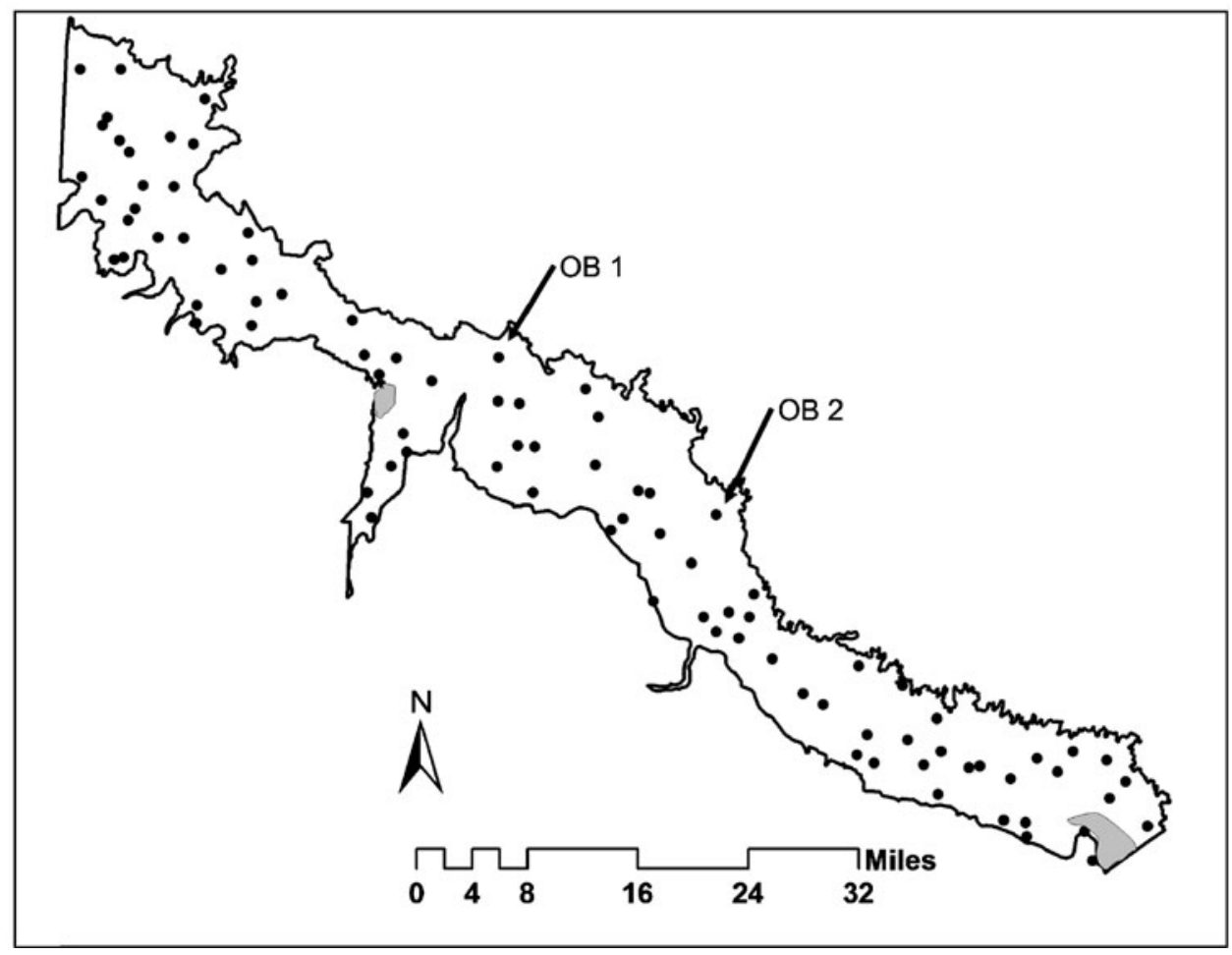

Figure 3. Aquifer map showing: (a) the finite-difference grid and model boundary conditions; (b) the distribution of observation wells.

Aquifer discharge through the main spring at Boiling Springs Park was also simulated with a drain cell. Average spring discharge (data obtained from the Park's office) was $164 \mathrm{~m}^{3} /$ day. In both cases, drain conductances were first assigned arbitrarily and then modified during model calibration. The two reservoirs, Fort Supply and Canton Lakes, located within the model domain, were represented by constant head cells. Recharge to the aquifer was applied to the top model layer. Six recharge zones were created based on surface geology and soil types. Average annual recharge was then varied 
spatially over the zones based on precipitation. Direct precipitation recharge was assumed to be $10 \%$ of annual precipitation (e.g., Bartolino 2007). Consistent with the pattern of precipitation across the study area, the recharge was varied from $6.96 \times 10^{-5} \mathrm{~m} /$ day in the western part of the aquifer to $1.39 \times 10^{-4} \mathrm{~m} / \mathrm{d}$ in the southern part, with an average of $1.03 \times 10^{-4} \mathrm{~m} / \mathrm{d}$. Irrigation return flow was assumed to be $20 \%$ of annual irrigation pumpage (e.g., Davis and Christenson 1981). However, this amount was not added explicitly as recharge in the model. Instead, reported irrigation withdrawal, for which data were more reliable, was reduced by $20 \%$, which has the same effect as adding an equivalent amount of return flow. Direct groundwater evapotranspiration $\left(E_{p}\right)$ was not simulated in the model because there was not enough information. Moreover, the likely aquifer area contributing $E_{p}$ (i.e., vegetated area where the water table is within $3 \mathrm{~m}$ of the land surface) is less than $1 \%$ of the model area. Groundwater pumping was specified in the model at 131 nodes representing actual locations of pumping wells.

Stream-aquifer interaction was simulated with the streamflow routing package (STR 1) developed for MODFLOW by Prudic (1989). The STR package tracks the amount of water in each simulated stream segment and computes the fluxes between surface streams and groundwater. Stream stage was computed iteratively using the Manning's roughness coefficient. This approach is superior to that used in the river package where river stage must be kept constant for each stress period. Simulations were performed for both steady and non-steady state conditions. The BNCR and its tributaries were simulated as head-dependent flux boundaries. All rivers were simulated as partially penetrating with leaky riverbeds. Along a river segment, each model cell constitutes a river reach; hence, the entire river system consisted of 502 reaches. Digital data for different river segments, including average flows and channel characteristics (e.g., stage, slope, width, and Manning's roughness coefficient) were obtained from the USEPA's BASINS program (version 3.1). BASINS is a multipurpose environmental analysis system that integrates a geographic information system (GIS), national watershed data, and other environmental assessment and modelling tools into a single package. The program is available for free download at www.epa.gov/waterscience/basins. Within the BASINS program is the Reach File (RF1) package containing a database of approximately $1126,300 \mathrm{~km}$ of streams with related hydrologic data for the conterminous United States. The RF1 package was queried for specific data on the BNCR watershed. Additionally, stream discharge data was available at four USGS gauging sites (www.waterdata.usgs.gov/ok/nwis) located in the study area.

\section{Model calibration}

The groundwater model was calibrated to both quasi-steady-state (QSS) and transient conditions. The term QSS is used because groundwater exploitation within the aquifer began long before the period used for the steady-state calibration. In a prior study, Davis and Christenson (1981) had used the 1978-1979 period to simulate predevelopment conditions for the aquifer. A review of the OWRB's long-term groundwater level records (1976-2004) led to the adoption of the same period in this study. Consequently, average groundwater levels for the period were used as targets for the QSS calibration. The OWRB groundwater level records are annual averages of measurements made during the winter months (DecemberMarch) when both anthropogenic and evapotranspiration demands are minimal. The network of monitoring wells includes those specifically drilled for observation purposes and several abandoned wells across the aquifer. Records from 91 of the wells were used for model calibration in this study.

Calibration to both QSS and transient conditions ensures that observed and simulated conditions are also matched at multiple time steps thereby reducing uncertainty in parameter estimates (e.g., Allen et al 2004; Brouyère et al 2004). The QSS calibration was achieved with the automatic parameter estimation program, PEST (Doherty 2001). PEST automatically adjusts model parameters until the fit between model outputs and observations is optimized. The program also allows the inclusion of simple empirical formulae relating two or more parameters, and it likewise, permits the user to limit the interval over which each parameter can be varied; thus keeping the optimized parameters within acceptable limits. The QSS calibration matched calculated hydraulic heads and average groundwater level elevations in observation wells. To strengthen the calibration, simulated stream stages were also compared with recorded stages at four USGS streamflow gauging sites in the BNCR system (table 2).

The parameters adjusted automatically during the calibration process included the hydraulic conductivity $(K)$ and the specific storage $\left(S_{s}\right)$. To obtain a closer match between calculated and measured flows, additional parameters, including streambed/drain conductances, and Manning's roughness coefficient $(n)$, were tweaked manually, where necessary. The initial distribution of $K$ was previously described in the model development section. Because no prior data were available for streambed and drain conductances, their 
Table 2. Calculated vs. observed stream stages.

\begin{tabular}{lccc}
\hline Gauging station (period of record) & $\begin{array}{c}\text { Observed stage } \\
(\text { m.a.s.l) }\end{array}$ & $\begin{array}{c}\text { Calculated stage } \\
\text { (m.a.s.l) }\end{array}$ & $\begin{array}{c}\text { Difference } \\
(\mathrm{m})\end{array}$ \\
\hline USGS 07237500: Woodward (1905-2005) & 556.71 & 558.92 & -2.21 \\
USGS 07235600: Wolf Creek (1985-2005) & 595.50 & 598.71 & -3.21 \\
USGS 07238000: Seiling (1947-2005) & 509.41 & 511.18 & -1.77 \\
USGS 07239000: Canton (1938-2003) & 475.93 & 477.57 & -1.64 \\
\hline
\end{tabular}

initial values were assumed (see also McDonald and Harbaugh 1988). The above parameters were adjusted until observed and simulated hydraulic heads, as well as stream stages, were matched satisfactorily.

Transient model calibration was achieved by trial-and-error. The result of the QSS calibration provided initial conditions for the transient simulation. For this simulation, groundwater pumping was introduced over a 15-year period (19791994), incorporated into the model as a single stress period, and divided into 30 time steps. Calculated heads were saved at the end of each time step. The pumping rate at each pumping well was the average of actual withdrawal reported annually over the 1979-1994 period. These varied from 73 to $6393 \mathrm{~m}^{3} / \mathrm{d}$. Calibration was achieved by adjusting the specific yield $\left(S_{y}\right)$ until simulated heads matched annually-observed groundwater levels in observation wells. The process necessitated a slight adjustment of the previously adjusted parameters ( $K, n$, streambed conductances, and recharge) during the QSS calibration in order to match also simulated and observed fluxes (see details in section 6). Parameter values derived from the model calibration are provided in section 6 .

\section{Predictive scenarios}

Three sets of predictive model runs were performed to evaluate the response of the A\&T aquifer to different stress scenarios. These include:

- a water demand scenario, which assesses the response of the aquifer to regional anthropogenic water demand as projected by the OWRB;

- two recharge scenarios, a severe drought and a prolonged wet period, that are designed to reflect the effects of climate variability; and

- an adaptive scenario, simulated to account for improved water management strategies on the A\&T aquifer.

Using the 1990 water demand as the baseline, the OWRB predicted that water demand in northwestern Oklahoma will be approximately $53 \%$ higher by the year 2050 (OWRB 1997). Note however that the above projection is based on consideration of both surface and groundwater. Even so, groundwater from the A\&T aquifer is the principal regional source of water; this study treats the projected demand as a direct scenario on the aquifer. Thus, for purposes of this study, the reported 1990 groundwater withdrawal from the aquifer is increased linearly according to the OWRB-projections. In the model, the demand scenario is represented in a $60-\mathrm{yr}$ model run (1990-2050) divided into six stress periods, each a decade long. During the simulation, model-calibrated recharge was held constant, while groundwater withdrawal at each well and for each stress period was varied according to the projected water demand for the corresponding decade. Total annual withdrawal under this scenario varied from $131,000 \mathrm{~m}^{3} / \mathrm{d}(1990)$ to $202,000 \mathrm{~m}^{3} / \mathrm{d}(2050)$.

Two recharge variability scenarios, envisioned as deviations from the normal amounts of groundwater recharge forced by climate, were simulated. For purposes of this study, a recharge scenario is defined by an assumed percentage of the modelcalibrated (normal) recharge (e.g., Rainwater et al 2005). The first recharge scenario simulated was a 'severe drought', which spanned over a 4-year period, consistent with the worst drought (in terms of duration; 1953-1956) on recent historical precipitation record (1894-2010) for the study area (refer to figure 2). This period also has the highest cumulative precipitation deficit on the record. In the model, the severe drought was represented as a 4 -yr stress period during which the calibrated aquifer recharge was assumed to be reduced by $50 \%$. It was also assumed that such prolonged dry conditions will lead to a doubling of normal aquifer pumping; hence, the pumping rate at each withdrawal well was doubled for the stress period. Normal pumping here refers to the average aquifer withdrawal for the 2000-2004 period. This pumping period was chosen in order to utilize pumping data for a period with the most current well distribution for model projections. A second consideration was data availability and quality - higher data quality was assured for this period and the data were more complete for individual wells. The drought scenario was performed to assess the response of the A\&T aquifer, should a severe drought, comparable in magnitude and 
duration to the 1953-1956 droughts occur in the future in northwestern Oklahoma.

The last recharge scenario simulated a prolonged wet period to assess how the A\&T aquifer might respond to a potentially wetter climate. From the historical precipitation record in figure 2, the longest wet period occurred between 1902 and 1909. This duration was simulated in the model with a stress period, that is, 8 years long. The wet condition was simulated with an assumed $30 \%$ increase of the normal aquifer recharge over the 8year period. Similarly, it was assumed that the wet conditions will reduce pumping at each well, during the entire period, by $50 \%$.

Finally, a scenario that assumes improvements in water conservation measures (e.g., the use of more efficient irrigation technologies) was simulated. For this scenario, the normal model-calibrated recharge was used. However, it was assumed that human adjustments will reduce aquifer-wide groundwater pumping by $25 \%$. Note that for irrigation wells, the seasonality in pumping was factored into the model by simulating the seasons as separate stress periods. Results of the simulations are discussed in the next section.

\section{Results and discussions}

\subsection{Calibration}

Figure 4(a) uses isopleths to illustrate the strong agreement between simulated and observed
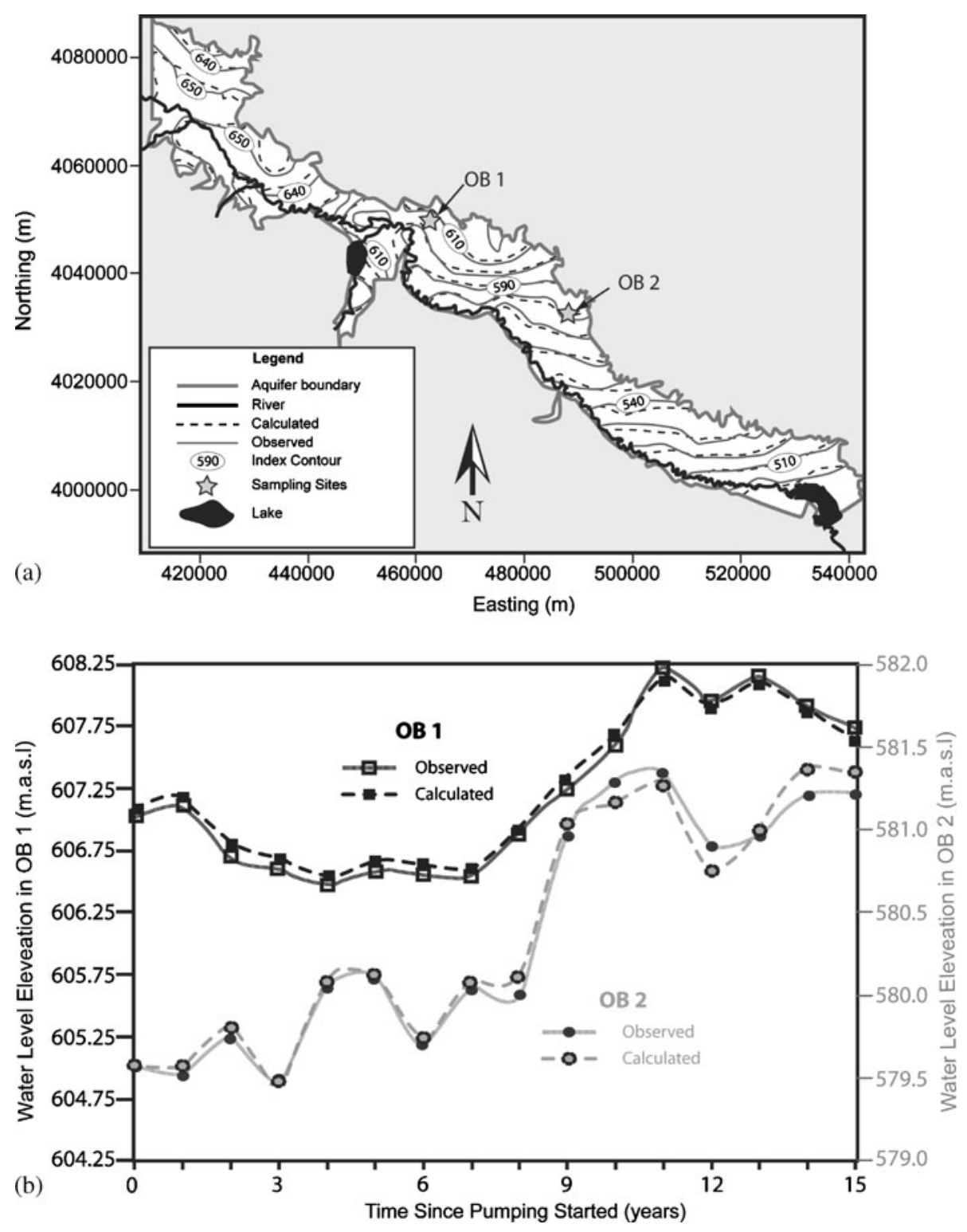

Figure 4. (a) QSS calculated vs. observed head contours, (b) calculated vs. observed groundwater elevation at two observation wells (transient) (adapted from Zume and Tarhule 2006). 
hydraulic heads for the quasi steady-state (QSS) calibration, while results of the calibrated stream stages are shown in table 1 . For the heads, analysis of the level of agreement at individual well points indicate that $29 \%$ of the 91 observation points, had residuals between 0 and $\pm 1.5 \mathrm{~m}, 47 \%$ between \pm 1.5 and $\pm 2.5 \mathrm{~m}$, and $20 \%$ between \pm 2.5 and $\pm 3.5 \mathrm{~m}$. Only $4 \%$ had residuals greater than $3.5 \mathrm{~m}$. The mean of the absolute residual (MAR) was $2.34 \mathrm{~m}$, which is within the combined error range of both the USGS 7.5 -minute $(30 \times 30 \mathrm{~m})$ digital elevation model (DEM) used to derive water level elevations, and the errors in the water level measurement. The agreement between simulated and observed groundwater levels for the transient calibration is shown in figure 4(b) for two of the 91 observation wells (OB 1 and OB 2).

Calibrated hydraulic conductivity $(K)$ values for the aquifer range from 0.78 to $65 \mathrm{~m} / \mathrm{d}$, with an average of $30.81 \mathrm{~m} / \mathrm{d}$. The value of $K$ at the low end is consistent with that reported by Davis and Christenson (1981) for the aquifer, but the upper limit is significantly higher than their results $(49 \mathrm{~m} / \mathrm{d})$. However, Wood and Stacey (1965) reported $K$ values of up to $61 \mathrm{~m} / \mathrm{d}$ for the aquifer, which is reasonably close to the upper value of $K$ obtained in this study. Overall, simulated heads and stages matched observed conditions satisfactorily. The specific yield $\left(S_{y}\right)$ obtained for the aquifer is 0.28 . This compares favourably with the value of 0.29 reported by Davis and Christenson (1981). Model-derived streambed conductances range from 63 to $6038 \mathrm{~m}^{2} / \mathrm{d}$ for different reaches of the BNCR, while Manning's $n$ values ranged from 0.045 to 0.060 .

The simulated QSS potentiometric surface (figure 4a) indicates groundwater level slopes in a northwest-southeast direction consistent with basin topography; consequently, flow is generally southwesterly towards the BNCR. On the northern end of the aquifer, around the NW part of Harper County (refer to figure 1), potentiometric contours indicate groundwater discharges from the aquifer into adjacent basins. Similarly, there is indication that groundwater seeps into the aquifer from the adjacent Ogallala Formation in southwestern Harper County, near its border with Beaver County.

The mass balance for the calibrated model shows that direct precipitation recharge is the major input to the aquifer (66\%), followed by stream leakage, which accounts for $30 \%$ of aquifer recharge. Groundwater seepage from the adjacent Ogallala Formation and upper end alluvium constitutes 3\% of total inflow, while seepage from the Fort Supply Lake accounts for roughly $1 \%$. On the output side, groundwater discharge to streams (baseflow) is the largest source of outflow from the aquifer
$(56 \%)$. Groundwater also exits the aquifer into lakes $(32 \%)$, adjacent groundwater basins (11\%), and as spring flow $(<1 \%)$. These results are consistent with those reported by Davis and Christenson (1981) for this aquifer, and those for similar aquifers in western Oklahoma (e.g., Adams and Bergmann 1996). The above results suggest that both natural climatic variability that alters the amount and timing of precipitation, and anthropogenic groundwater pumping, can have profound impact on aquifer recharge, and similarly, baseflow contribution to streams.

\subsection{The demand scenario}

Figure 5 shows results obtained by simulating the projected demand on the A\&T aquifer. The simulation was run from 1990 through 2050 with results saved at the end of each decade. Figure 5(a) shows drawdown and saturated thickness averaged over the entire aquifer at the end of each decade, caused by the projected pumping. Notice that, on average, drawdown increases from $0.73 \mathrm{~m}$ at the end of 2000 to $1.95 \mathrm{~m}$ at the end of 2050 , with a corresponding decrease in the aquifer saturated thickness, which is expected for an unconfined aquifer. A clearer picture is obtained when the simulated impacts are also viewed spatially across the aquifer (figure $5 \mathrm{~b}$ ). For brevity however, only the spatial pattern of drawdown at the end of 2050 is shown. This pattern is, nonetheless, similar to those for the earlier decades differing slightly, only in drawdown magnitudes (shown as graduated shading in figure $5 \mathrm{~b}$ ). The graduated shading indicates drawdown magnitudes. The non-shaded areas are those experiencing no drawdown or even water table recovery. A comparison of figure 5(b) with a map of well distribution over the aquifer (figure $5 \mathrm{c}$ ) shows a strong correlation between drawdown magnitude and pumping well density. For example, the area of maximum drawdown (middle portion) also corresponds with the densest well cluster in the aquifer. Not investigated explicitly on the figure are the roles of pumping intensity and geologic heterogeneity, which can both impact drawdown magnitudes. However, there is reason to believe that the intensity of pumping is the major player in depleting the aquifer. Note, for example, that the location with the highest drawdown magnitudes (around the mid portion of the aquifer) correlates with the location of irrigation wells, and wells used for power supply, that are large-capacity wells having the highest average withdrawal rates. As observed in figure 5(b), only about $26 \%$ of the aquifer will experience drawdown of greater than $1 \mathrm{~m}$ under the projected pumping. This suggests that spatially, impacts of 


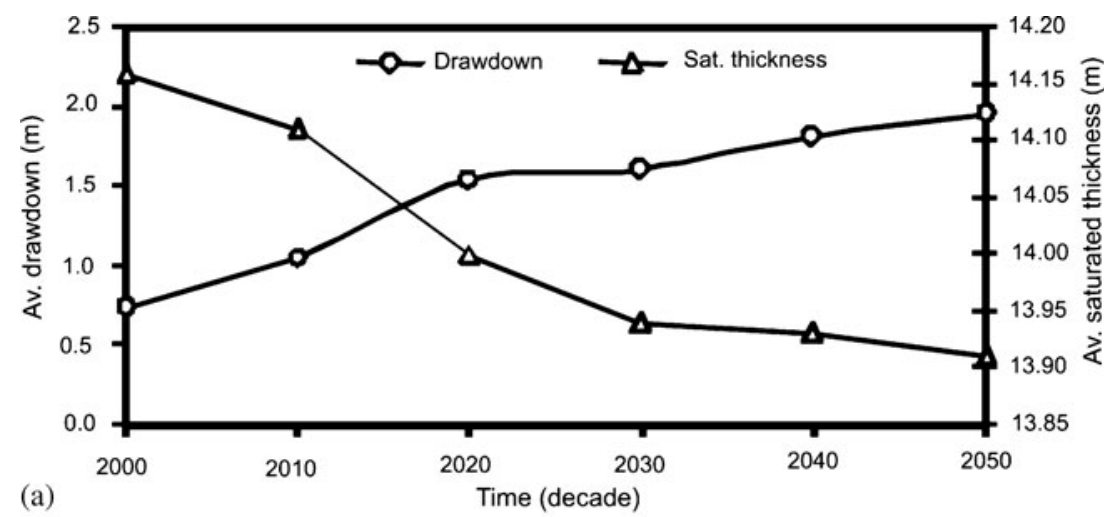

(a)

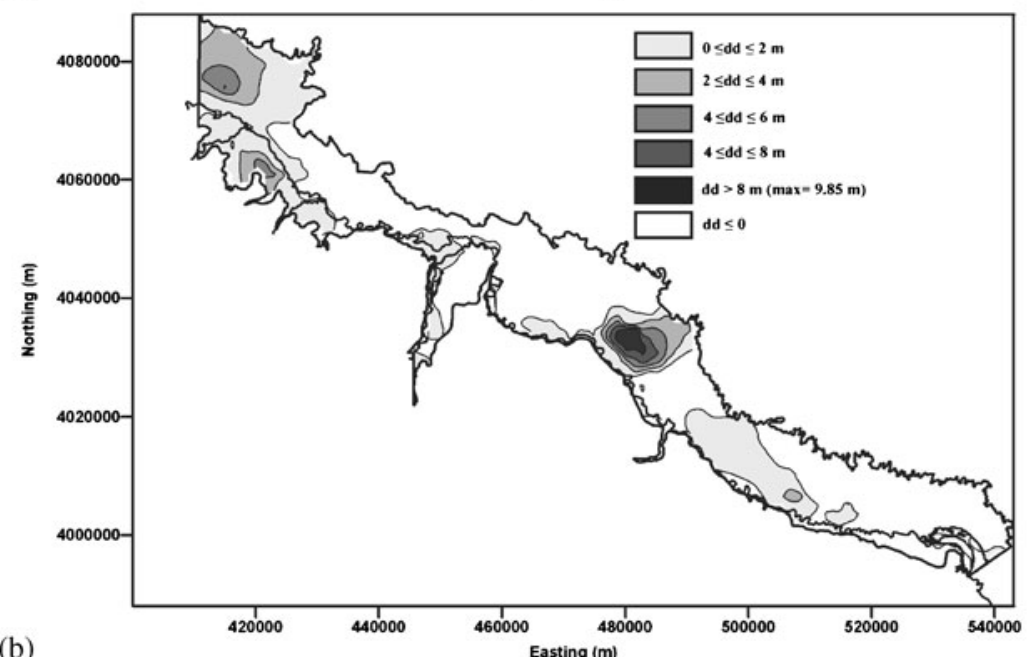

(b)

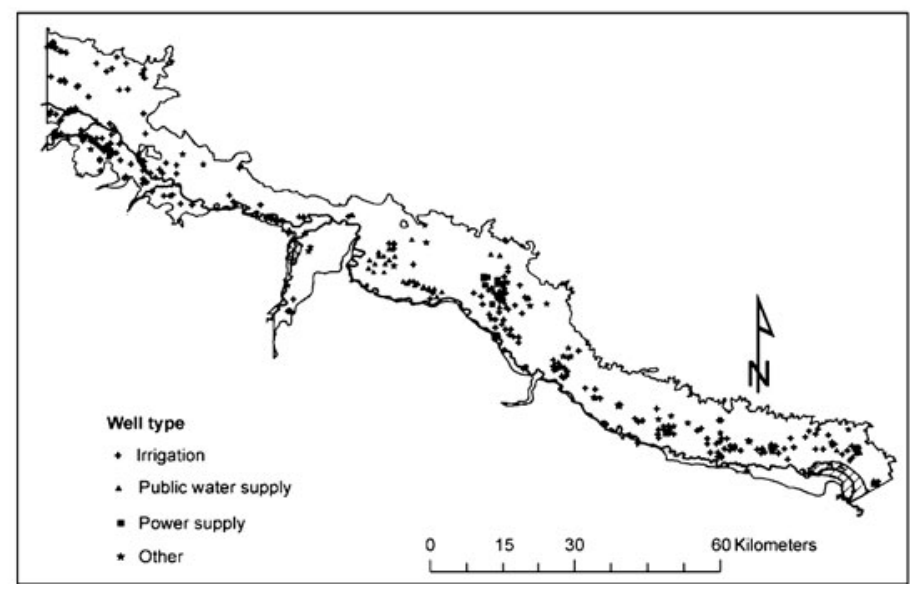

Figure 5. (a) Average drawdown and saturated thickness; (b) drawdown at the end of year 2050 (demand scenario); and (c) pumping well distribution within the study aquifer.

the projected pumping scenario on the aquifer will be localized, most likely around areas of high well density and pumping intensity.

Another impact of the projected pumping on the aquifer, and perhaps, the most significant, is that on stream-aquifer interaction. Figure 6 shows the interaction between the A\&T aquifer and its overlying surface water system (the BNCR system). In alluvial plains, streamflow depletion can result from aquifer pumping in two ways: (1) when pumping reduces baseflow contribution to streams, and (2) when pumping creates cones of depression around wells that expand to the stream and induce stream water loss into the aquifer (referred to here as 'stream leakage'). Losses from these two sources constitute total stream depletion (Chen and Yin 2001; Chen 2003). To isolate the impacts of pumping on stream-aquifer interaction, a transient model was first run with no pumping introduced (figure 6a). Then the model was re-run with the projected pumping scenario (figure $6 \mathrm{~b}$ ). Note that the baseflow and stream leakage in figure 6 


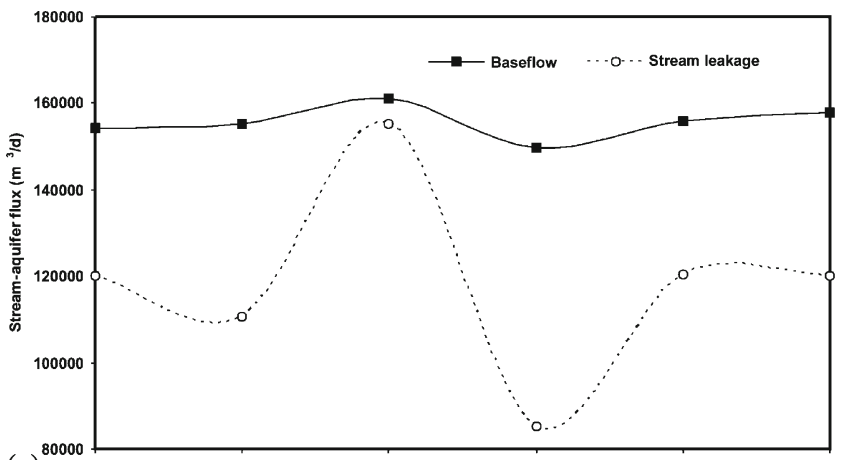

(a)

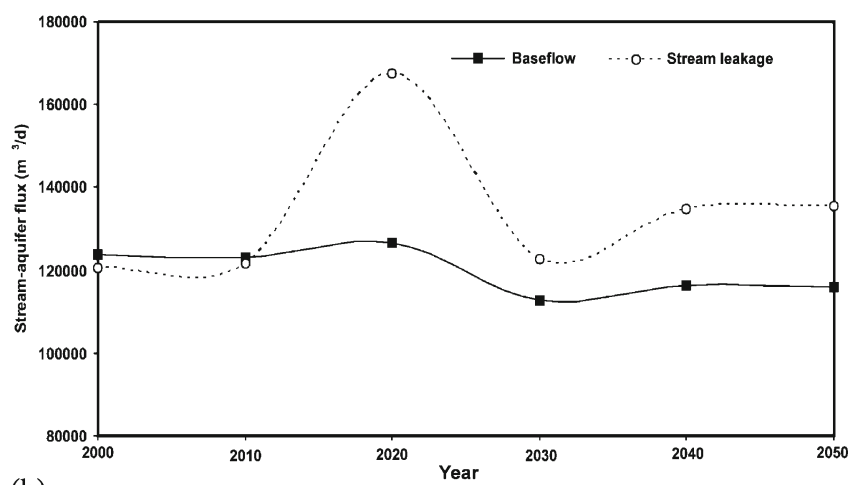

(b)

Figure 6. Stream-aquifer interaction (a) no pumping, (b) demand-scenario pumping.

are the total of each component over all stream reaches. In the first run (figure 6a) baseflow contribution to the stream is higher than stream leakage at all pumping times, signifying that the BNCR is a gaining system under non-pumping conditions. This result is consistent with that reported earlier under the QSS calibration. In the second model run (with pumping; figure 6b) however, results indicate that relative to the non-pumping state, baseflow will reduce by $27 \%$ while stream leakage will increase by $13 \%$ for a total streamflow depletion of $40 \%$. As a result, the BNCR would become a losing system beyond the year 2010 (see the crossover point on figure $6 \mathrm{~b}$ ).

\subsection{Recharge variability scenarios}

Figure 7 summarizes the impacts of the simulated recharge variability scenarios on the $\mathrm{A} \& \mathrm{~T}$ aquifer. The top panel (figure 7a) compares simulated average drawdown created by the two recharge variability scenarios with the actual. Note that the actual drawdown is the aquifer-wide average obtained from a simulation using the actual 2000-2004 average annual withdrawal from the aquifer and the model-calibrated recharge. The results suggest that a 'severe drought' comparable in magnitude and duration to the 1950s drought would create drawdown in the A\&T aquifer that is more than double the current (actual) shown. A cell by cell examination of the model results show that aquiferwide, drawdown would range from 0 to $>12 \mathrm{~m}$, with an average of $2.03 \mathrm{~m}$. This is significant given that drawdown magnitudes on the order of even a few centimeters can have profound impact on basin ecosystems (Kirshen 2002). Comparatively, the maximum average drawdown of $12.46 \mathrm{~m}$ under the severe drought scenario is about $26 \%$ more than the maximum under the 'projected pumping' scenario (at the end of 2050). This is reasonable because a drought does not only deprive the aquifer of a significant amount of recharge but also induces aquifer overexploitation.

Simulation results for the very wet scenario suggest that average drawdown in the A\&T aquifer will be reduced by $94 \%$ relative to the actual drawdown conditions. Under this scenario, maximum drawdown at any point within the aquifer will be less than $5 \mathrm{~m}$. Results also show that stream depletion will no longer be an issue because of increased baseflow and diminished stream leakage. Thus, under this scenario, the BNCR system remains an effluent system throughout the simulation period.

Figure 7(b) shows the spatial distribution of drawdown simulated under the severe drought scenario. The pattern looks similar to that discussed earlier for the demand scenario (figure 5b), except that drawdown magnitudes are higher on average in this case. Similarly, the aquifer area experiencing drawdown is also approximately $13 \%$ larger under the severe drought scenario.

The severe drought scenario induces similar impacts on stream-aquifer interaction as previously described for the projected pumping scenario. Under this scenario, the current flow in the BNCR system will be depleted by $89 \%$. Approximately $59 \%$ of the total depletion will be due to reduced baseflow. Recall that majority of the BNCR reaches depend heavily on baseflow contributions from the A\&T aquifer; thus, the above result mean that a severe drought will deprive the BNCR of $59 \%$ of its source of discharge, turning it into a losing stream.

\subsection{The human adjustment scenario}

Under the human adjustment scenario, it was assumed that improved human water conservation measures in the future will result to, at least, a $25 \%$ (arbitrary chosen) reduction in aquifer withdrawal. Simulated results for this scenario are also referenced to the 2000-2004 average pumping conditions (actual). The results suggest that on average drawdown in the aquifer will reduce by approximately $12 \%$ relative to the actual conditions. As a result, the average saturated thickness 


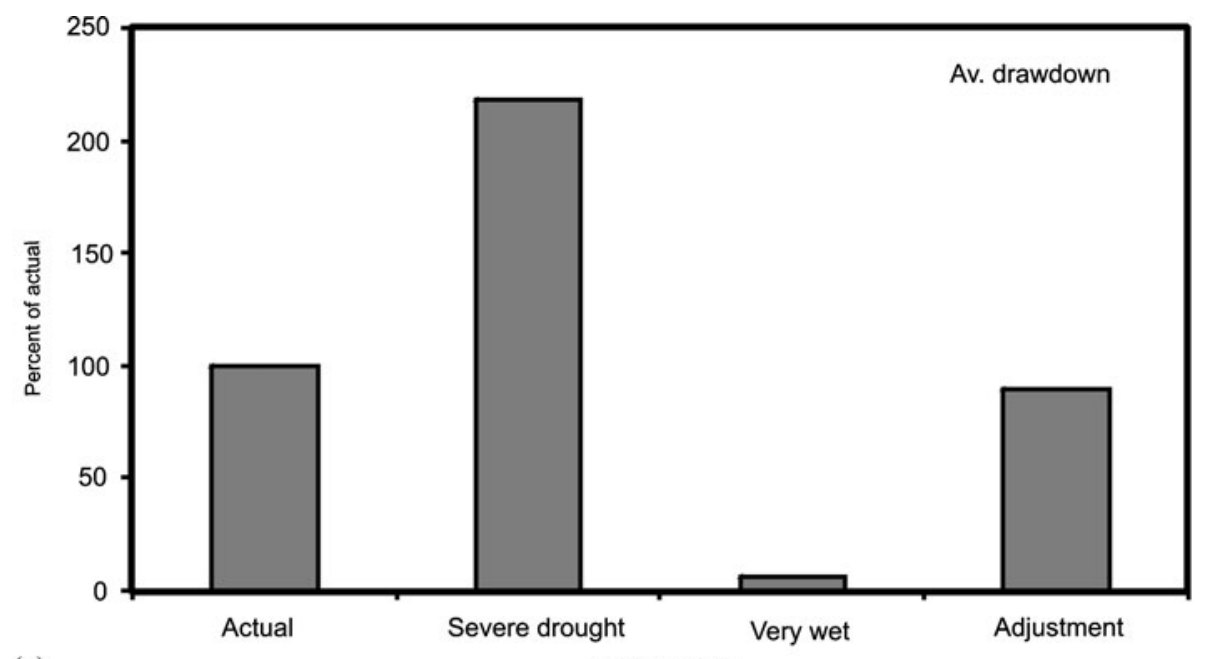

(a)

Model scenario

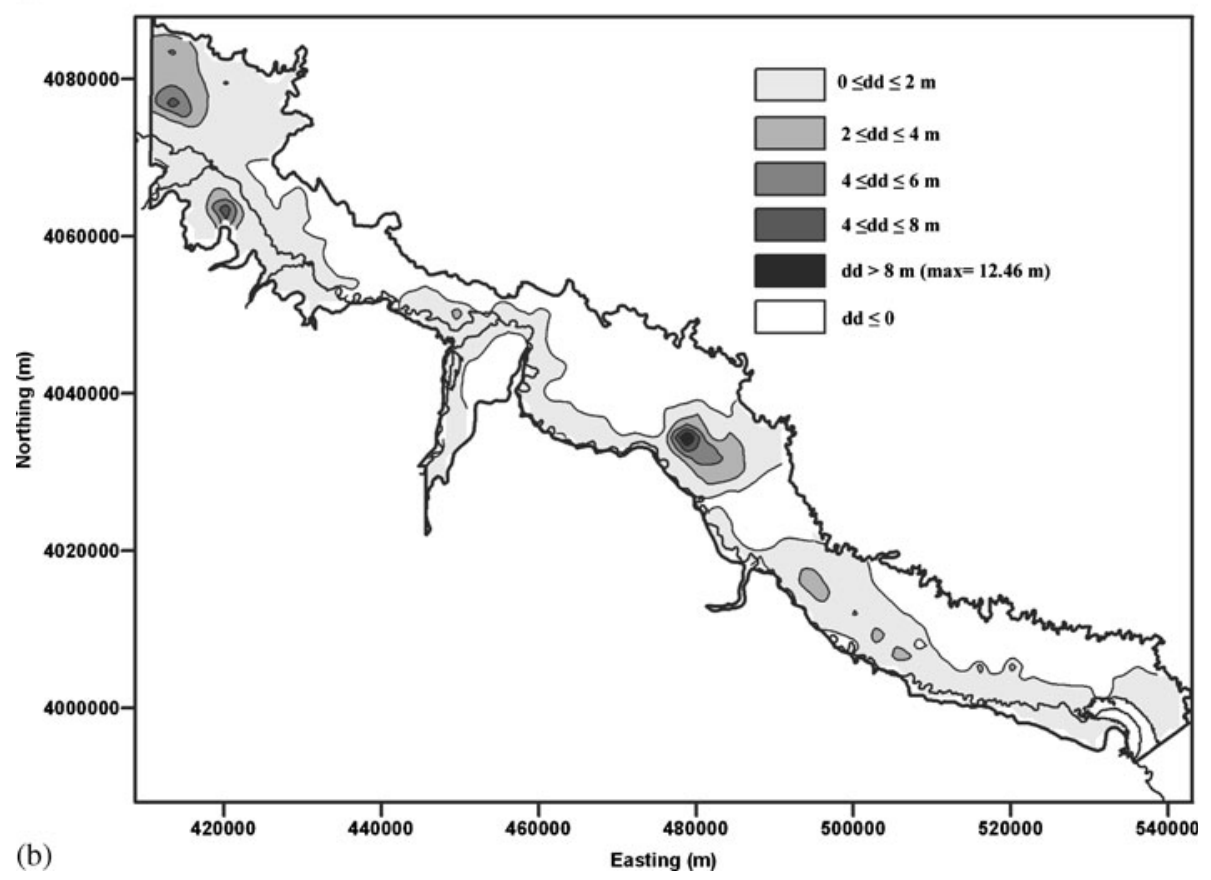

Figure 7. (a) Average drawdown for climate variability scenarios, (b) projected drawdown (spatial) under the severe drought scenario.

will increase by approximately $9 \%$. The impact of the hypothetical $25 \%$ reduction in aquifer pumping will translate to a $20 \%$ (approximately) increase in streamflow due to increased baseflow contribution and reduced stream leakage. This result underscores the significance of improved aquifer management strategies on both groundwater and surface water/groundwater interaction.

\section{Model post-audit}

We took advantage of the availability of water level data beyond the modelling period to compare model-predicted aquifer drawdown for 2010, simulated with the 'demand scenario' (see section 5), against measured (observed) drawdown. Observed drawdown was computed as the difference between the 2010 and the 2000 water levels. The results show that the predicted and the observed drawdown patterns are generally similar spatially. For example, the 2010 observed maximum drawdown occurs in the same location as that predicted by the model. On the other hand, two new areas of moderate aquifer drawdown are observed where the model originally predicted none or even water table recovery (figure 8a). In terms of drawdown magnitudes, however, the model overpredicted the actual values. Specifically, the actual maximum aquiferwide drawdown measured in 2010 was $4.68 \mathrm{~m}$ which is $35 \%$ lower than the $7.12 \mathrm{~m}$ predicted by the model. 

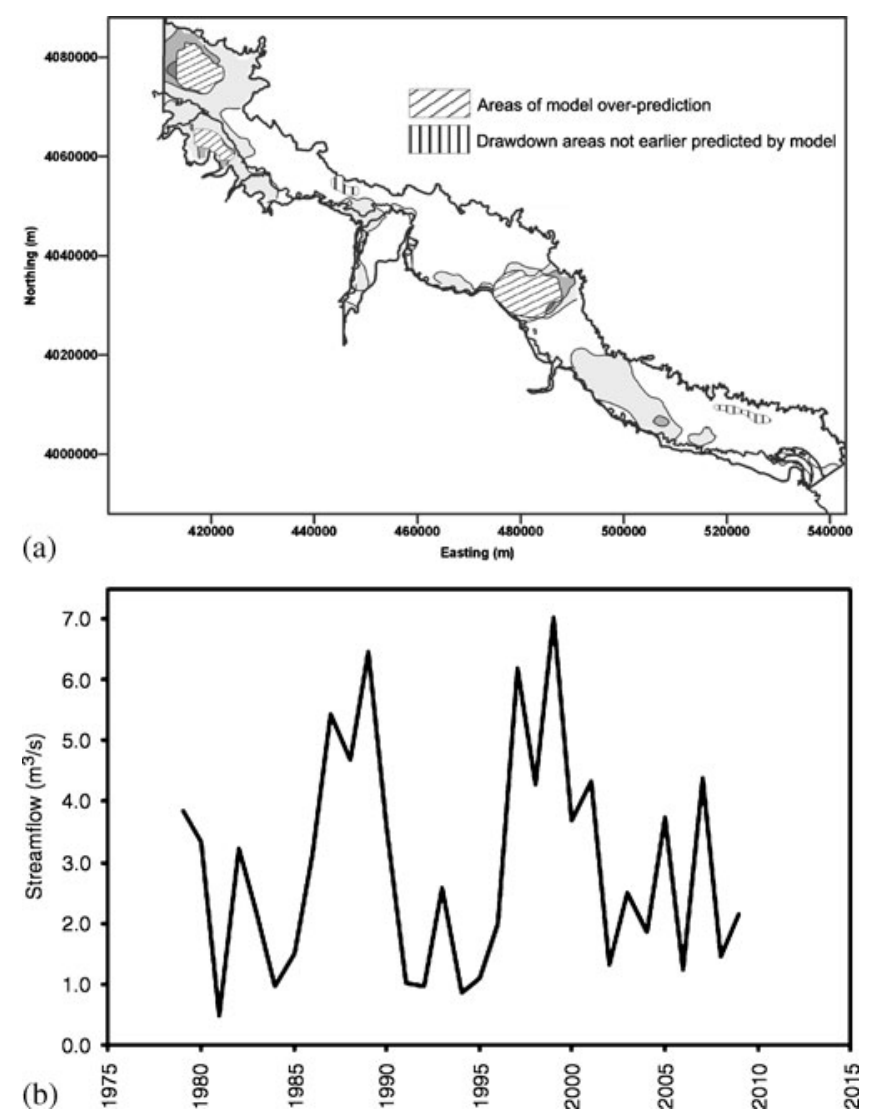

Figure 8. (a) Summarised result of model post-audit; (b) stream discharge for the BNCR gauge at Woodward.

In particular, the model overpredicted drawdown in three areas (essentially those areas where the original model predicted the highest drawdowns) by a factor of 2 approximately (refer figures 8 and $5 \mathrm{~b}$ ). We attribute the observed milder drawdowns, relative to the predicted, to the excessively wet period between 2007 and 2008 (refer figure 2). Such wet conditions simultaneously enhance recharge as well as reduce water demand from an aquifer, allowing water levels to recover. The post-audit did not include new segment-by-segment simulation of the BNCR to evaluate stream-aquifer interaction. However, observed, discharge records for the model-simulated BNCR segments continue to show declining trends for the period 2002-2009 (figure 8b), consistent with the model prediction that the BNCR will become a losing system beyond 2010 .

Overall, therefore, the model predicted the spatial pattern of drawdown reasonably with only minor differences around a few individual well points. The model overpredicted the drawdown, reflecting the difficulty of predicting a system that depends not only on natural hydrologic dynamics but also on anthropogenic impacts (Oreskes and Belitz 2001). Encouragingly, the observed differences are consistent with those reported elsewhere (e.g., Stewart and Langevin 1999; Anderson and Lu 2003; Bredehoeft 2003, 2005).

\section{Summary and conclusions}

Alluvial aquifers are a critical source of water in semi-arid regions throughout the world. They support human economic activities such as irrigation, domestic, and municipal water supplies as well as sustain aquatic ecological systems. However, increased pressure on these aquifers from population growth, irrigation water demand, and climate variability threatens to undermine their sustainable use. This study implemented a numerical groundwater flow model of the A\&T aquifer in northwestern Oklahoma to evaluate the potential impacts of anthropogenic groundwater withdrawal and recharge variability on aquifer dynamics, including stream-aquifer interactions. The results indicate that direct precipitation recharge is the primary source of inflow to the modelled aquifer $(66 \%)$, and under non-pumping conditions, groundwater discharge (baseflow) to streams, constitutes the largest outflow from the aquifer (56\%). Using a projection of water demand by the OWRB, the study showed that average drawdown (under the demand scenario) in the A\&T aquifer, would range from $0.73-1.95 \mathrm{~m}$ between 2000 and 2050 . However, areas of high drawdown will be localized around clusters of high intensity pumping wells. Correspondingly, the aquifer saturated thickness 
would decrease with each decade of pumping. The demand scenario would also decrease baseflow with time, and induce stream leakage from overlying streams so that by 2050 , baseflow would be reduced by $27 \%$ and stream leakage increased by $13 \%$. Under these conditions, the BNCR switches from a gaining system to a losing beyond 2010. On the basis of the simulation results, it is shown that the demand scenario would have a larger impact on stream-aquifer interaction compared to the drawdown picture obtained. This finding poses a lesson for aquifer investigations in general. For example, were the aquifer the only focus of this investigation, perhaps, it might be wrongly concluded that the projected pumping would have little effect on long-term aquifer function when realistically, there is a substantial effect on stream-aquifer relations. For holistic aquifer management purposes, therefore, aquifer studies should evaluate all aspects of aquifer dynamics that possibly, may be impacted by imposing stresses.

Two recharge variability scenarios were simulated namely, a severe drought and a prolonged wet period. The impacts of these scenarios on groundwater levels and stream-aquifer interactions were compared with those for actual conditions. Results show that the severe drought for example, would exacerbate drawdown in the aquifer (values ranging from 0 to $12.46 \mathrm{~m}$ with an average of $2.03 \mathrm{~m}$ ). Such magnitude of drawdown would contribute to streamflow depletion in the BNCR system by $89 \%$. The results of the very wet scenario indicate favourable conditions for the aquifer as drawdown aquifer-wide will be minimal $(<6 \%)$. Under this scenario, the BNCR system will return to its pre-development gaining status. Finally, a scenario that assumed positive human adjustments in water use practices was also simulated. Results suggest this condition would reduce average drawdown in the aquifer by approximately $12 \%$. Under this scenario, stream depletion would reduce by $20 \%$.

A post-audit of the model was carried out to compare the model predicted drawdown for the year 2010, simulated under the OWRB demand scenario, with the observed or measured drawdown. Results show that the model predicted the spatial pattern of drawdown reasonably with only minor differences around a few individual well points.

Overall, results of this study have demonstrated the important influence that future climate and anthropogenic water demand may exert on the $\mathrm{A} \& \mathrm{~T}$ aquifer. By and large, the results provide information that can be used for evaluating alluvial aquifer management options, as well as a basis for regulating stream-aquifer relations that protect dependent aquatic ecosystems.

\section{Acknowledgements}

The authors would like to acknowledge the following agencies for data support: The Oklahoma Water Resources Board (OWRB), the U.S. Geological Survey (USGS), and the U.S. Environmental Protection Agency (US EPA).

\section{References}

Abderrahman W A and Rasheeduddin M 1994 Future groundwater conditions under long-term water stresses in an arid urban area; Water Resour. Manag. 8 245-264.

Adams G P and Bergmann D L 1996 Geohydrology of alluvium and terrace deposits of the Cimarron River from Freedom to Guthrie, Oklahoma; U.S. Geological Survey Water-Resources Investigations Report 95-4066, 57p.

Adams G P, Donna R and Alan R 1997 Digital datasets that describe aquifer characteristics of the alluvium and terrace deposits along the BNCR from the Panhandle to Canton lake in Northwestern Oklahoma; U.S. Geological Survey Open-file report 96-447.

Alemayehu T, Furi F and Legesse D 2007 Impact of water overexploitation on highland lakes of eastern Ethiopia; Envrion. Geol. 52 147-154.

Allen D M, Mackie D C and Wei M 2004 Groundwater and climate change: A sensitivity analysis for the Grand Forks aquifer, southern British Columbia; Hydrogeol. J. 12 270-290.

Anderson P F and Lu S 2003 A post audit of a modeldesigned groundwater extraction system; Groundwater 41(2) 212-218.

Bartolino J R 2007 Assessment of areal recharge to the Spokane Valley-Rathdrum Prairie aquifer, Spokane County, Washington, and Bonner and Kootenai Counties, Idaho; U.S. Geological Survey Scientific Investigations Report 2007-5038, 38p.

Bredehoeft J D 2003 From models to performance assessment: The conceptualization problem; Groundwater 41(5) 571-577.

Bredehoeft J 2005 The conceptualization model problemsurprise; Hydrogeol. J. 13(1) 37-46.

Bronstert A, Hauschild M and Doll P et al 2000 Integrated modelling of water availability and water use in the semi-arid Northeast Brazil; Physics and Chemistry of the Earth, Part B: Hydrology, Oceans and Atmospheres 25(3) 227-232.

Brouyère S, Carabin G and Dassargues A 2004 Climate change impacts on groundwater resources: Modeled deficits in a chalky aquifer, Geer Basin, Belgium; Hydrogeol. J. 12 123-134.

Cater R C and Alkali A G 1996 Shallow groundwater in the northeast arid zone of Nigeria; Q. J. Eng. Geol. 29(4) $341-355$.

Chen C C, Gillig D and McCarl B A 2001 Effects of climate change on a water dependent regional economy: A study of the Texas Edwards Aquifer; Climatic Change 49(4) 397-409.

Chen X H and Yin Y 2001 Streamflow depletion: Modelling of baseflow reduction and stream infiltration from seasonally pumped wells; J. Am. Water Resour. Assoc. 37(1) 185-195.

Chen X H 2003 Analysis of pumping-induced stream-aquifer interactions for gaining streams; J. Hydrol. 275 1-11.

Chen X and Chen X 2004 Simulating the effects of reduced precipitation on groundwater and streamflow in the 
Nebraska sand hills; J. Am. Water Resour. Assoc. 40(2) 419-430.

Christensen J H, Hewitson B, Busuioc A, Chen A, Gao X, Held I, Jones R, Kolli R K, Kwon W.-T., Laprise R, Magaña R V, Mearns L, Menéndez C G, Räisänen J, Rinke A, Sarr A and Whetton P 2007 Regional Climate Projections; In: Climate Change 200\%: The Physical Science Basis. Contribution of Working Group I to the Fourth Assessment Report of the Intergovernmental Panel on Climate Change (eds) Solomon S, Qin D, Manning M, Chen Z, Marquis M, Averyt K B, Tignor M and Miller H L, Cambridge University Press, Cambridge, United Kingdom and New York, USA.

Covich A P, Fritz S C and Lamb P J et al 1997 Potential effects of climate change on aquatic ecosystems of the great Plains of North America; Hydrol. Proc. 11 993-1021.

Croley T E and Luukkonen C L 2003 Potential effects of climate change on groundwater in Lansing, Michigan; J. Am. Water Resour. Assoc. 39(1) 149-163.

Cui Y and Shao J 2005 The role of groundwater in arid/semiarid ecosystems, northwest China; Groundwater 43(4) 471-477.

Davis R E and Christenson S C 1981 Geohydrology and numerical simulation of the alluvium and terrace aquifer along the Beaver-North Canadian River from the Panhandle to Canton Lake, Northwestern Oklahoma; U.S. Geological Survey, Open-file Report, 81-483.

Doherty J 2001 PEST groundwater data utilities; Brisbane, Australia: Watermark Numerical Computing, www.sspa.com/pest.

Don N C, Araki H, Yamanishi H and Koga K 2005 Simulation of groundwater flow and environmental effects resulting from pumping; Environ. Geol. 47 361-374.

Eckhardt K and Ulbrich U 2003 Potential impacts of climate change on groundwater recharge and streamflow in a central European low mountain range; J. Hydrol. 284(1-4) 244-252.

Holman I P 2006 Climate change impacts on groundwater recharge-uncertainty, the way forward; Hydrogeol. J. 14 637-647.

Kirshen P H 2002 Potential impacts of global warming on groundwater in eastern Massachusetts; J. Water Resour. Plann. Manag. 128 216-226.

Loáiciga H A, Maidment D R and Valdes J B 2000 Climatechange impacts in a regional Karst aquifer, Texas, USA; J. Hydrol. 227 173-194.

McDonald M G and Harbaugh A W 1988 A modular three dimensional finite-element groundwater flow model; Techniques of water resources investigations of the USGS Book 6, Chapter 1.

Mehl S, Hill M C and Leake S A 2006 Comparison of local grid refinement methods for MODFLOW; Groundwater 44(6) 792-796.

OWRB 19971995 Update of the Oklahoma comprehensive water plan; Publication of Oklahoma Water Resources Board no. 139.

Oreskes N and Belitz K 2001 Philosophical issues in model assessment; In: Model Validation: Perspectives in Hydrological Science (eds) Anderson M G and Bates P D, John Willey \& Sons Ltd.
Prudic D E 1989 Documentation of a computer program to simulate stream-aquifer relations using a modular, finite-difference, groundwater flow model; U.S. Geological Survey Open-File Report 88-729, 113p.

Rainwater K, Stovall J, Frailey S and Urban L 2005 Transboundary impacts on regional ground water modelling in Texas; Groundwater 43(5) 706-716.

Rejani R, Madan K, Jha M K, Panda S N and Mull R 2007 Simulation modelling for efficient groundwater management in Balasore coastal basin, India; Water Resources Management, Springer-online first, doi: 10.1007/s11269006-9142-z.

Rosenberg J, Epstein D J and Wang D et al 1999 Possible impacts of global warming on the hydrology of the Ogallala aquifer region; Climatic Change 42 677-692.

Ryder P D 1996 Groundwater atlas of the United States, Oklahoma, Texas; U.S. Geological Survey Publication, HA 730-E.

Senthilkumar M and Elango L 2004 3-dimensional mathematical model to simulate groundwater flow in the lower Palar River basin, southern India; Hydrogeol. J. 12(2) 197-208.

Stewart M and Langevin 1999 Post audit of a numerical prediction of well field drawdown in a semiconfined aquifer system; Ground Water 37(2) 245-252.

Tarhule A and Woo M 1997 Characteristics and use of shallow wells in a stream fadama: A case study in northern Nigeria; Appl. Geogr. 17(1) 29-42.

Tarhule A and Woo M K 2002 Adaptations to the dynamics of rural water supply from natural sources: A village example in semi-arid Nigeria; Mitigation and Adaptation Strategies for Global Change 7(3) 215-237.

USGCRP 2000 Climate Change Impacts on the United States. The Potential Consequences of Climate Variability and Change. Overview: Great Plains; Publication of the National Assessment Synthesis Team, US Global Change Research Program (www.usgcrp.gov/usgcrp/ Library/nationalassessment/overviewgreatplains.htm).

Varni M R and Usunoff E J 1999 Simulation of regionalscale groundwater flow in the Azul River basin, Buenos Aires Province, Argentina; Hydrogeol. J. 7 180-187.

Waterloo Hydrogeologic Inc. 2005 Visual MODFLOW v. 4.1, Premium edn. User's Manual, 611p.

Wilsnack M M, Welter D E and Montoya A M et al 2001 Simulating flow in regional wetlands with the Modflow wetland package; J. Am. Water Resour. Assoc. 37(3) 655-674.

Wood P R and Stacey B L 1965 Geology and ground-water resources of Woodward County, Oklahoma; Oklahoma Water Resources Board Bulletin 21, 79p.

Workman S R and Serrano S E 1999 Recharge to alluvial valley aquifers from overbank flow and excess infiltration; J. Am. Water Resour. Assoc. 35(2) 425-443.

Zume J T and Tarhule A 2006 Precipitation and streamflow variability in northwestern Oklahoma, 1894-2003; Phys. Geogr. 27(3) 189-205.

Zume J T and Tarhule A 2008 Simulating the impacts of groundwater pumping on stream-aquifer dynamics in semiarid northwestern Oklahoma, USA; Hydrogeol. J. 16 797-810. 